\title{
Conventional Implicatures of the 2019 Presidential Tribunal: Implications for the Nigerian Leadership, Media and Users
}

\author{
Emmanuel Chukwudi Ugwu \& Chukwuma Charles Motanya \\ http://dx.doi./org/10.4314/ujah.v20i3.14
}

\begin{abstract}
Conventional implicature deals with non-truth conditional content of the expression in any given situation. Nigerians went into the general election in the year 2019, which various positions were contested and so many conditions that took place. Political parties were at the helm of the affairs doing what they know how best to do, through manifestos, campaign, propaganda and so on. Later, there was outcome of the presidential tribunal, especially among the first and topmost two contenders in the election and actual implicature transpired in the judgement. The implication lies at what the majority sees as a rape of democracy and the court ruling. Language of affidavit became awash on the social media. So many non-truth conditions were generated on the media after the ruling. To ascertain this implicature, this study applied the qualitative research by using purposive sampling technique in gathering the data and its analysis. The study reveals the social vices in this situation against dwindling areas in our leadership and how it affects those using the language.
\end{abstract}

Keywords: Conventional, Implicature, Language, Affidavit, leadership, Presidential, Social Media.

\section{Introduction}

Nigerian is an entity that has a democratic and demographic structure, diversified into various beliefs and ideologies. The 
Ugwu \& Motanya: Conventional Implicatures of the 2019 Presidential Tribunal: Implications for the Nigerian Leadership, Media and Users

nation is well planned by amalgamation of various tongues, languages, views, dogmas, philosophies, religions and other various principles that have been upholding her. Her 1999 Constitution with 2011 Amendment section 2, sub-section 1 and 2 states thus:

Nigeria is one indivisible and indissoluble sovereign state

to be known by the name of the Federal Republic of Nigeria.

Nigeria shall be a Federation consisting of states and a Federal Capital Territory. (LL15)

Such indissoluble sovereign state goes to elect her leaders every four year since 1999, except in some states. After 2007 election, the nation had been conducting staggered elections due to squash or upturn of election from established various electoral tribunals and other higher appellate that has such discretion to do justice where there is electoral fraud and other irregularities. Sometimes laws are being interpreted and judgement delivered, using the language peculiar to the electoral rules. In all these, what could have caused nullifying of an election result after a winner had been declared by a competent body? What could cause a loser in any given election to seek redress in a competent court of law for actual interpretation of his/her grievances against the person that was declared winner of the said election?

Nigeria went and elected her leaders in the year 2015 between the month of February and March over the year's general election. The shocking aspect of it is that for the first time in the annals of history of Nigerian existence, where an incumbent President lost to the main opposition and did not go to any tribunal to reclaim the so called reclaimed mandate by the Nigerian lexicon. By 29th of May of 2015 the Winner was sworn in and the 
other elected positions. Year 2019 was another general election of the Nigerian people. Again two Saturdays in February and March 2019 were designated for the general election. The presidential and national assembly which comprise of the senatorial and federal constituency were first held. Later gubernatorial and state constituency were conducted after two weeks.

In fact, after these exercises couple with collation and declaration of rightful winners, the majority of the losers headed to electoral tribunal to claim and reclaim the so called stolen mandate given to their opponents. In the presidential election the incumbent President Muhammadu Buhari of the All People Congress was duly declared the winner and returned elected. His main opposition candidate Alhaji Atiku Abubakar prepared his grievances and lodged complaints with petition at the Court of Appeal with the peculiar number of CA/PEPC/002/2019. The petition was between him and his political party: Peoples Democratic Party (PDP) and the respondents were: Independent National Electoral Commission (INEC), Muhammadu Buhari and his party All Progressive Congress (APC).

One of the prayers of the petitioner against the 2nd respondent was that, that it may be determined that the 2nd Respondent was at the time of the election not qualified to contest the said election also, that it may be determine that the 2nd Respondent submitted to the commission affidavit containing false information of a fundamental nature in aid of his qualification for the said election. After long hearings and counter hearing that spanned months, the panel led Mohammed Lawal Garba, a Justice of Court of Appeal alongside other four justices, delivered its judgement on the 11th day of September 2019. Many hopes were elated while others were squashed. Before the judgement delivery social media were on great debate, languages were manipulated, so 
Ugwu \& Motanya: Conventional Implicatures of the 2019 Presidential Tribunal: Implications for the Nigerian Leadership, Media and Users

many calculations and assumptions were made. On the said issue of affidavit and its own judgement delivery, it was sifted, scrutinised, analysed by the followers of the judgement. Some electorates gave it various meaningful interpretations and implications on our leadership.

\section{Concepts of Implicature}

In some cases, words are written or uttered and the speaker or the hearer tries to mean totally different things from the actual things he or she has said or written, especially when the interactants have mutual understanding on what is on ground. Implicature occurs when flouting that is violation of the flow of thought takes place at the conversational maxims. Someone hyperbolically states in appreciation says, "a million thank to you all," it is left to discussants to agree whether the thanks run into millions. Jef Verschueren is of the opinion that the "term 'implicature' was introduced by the philosopher of language Paul Grice to cover a variety of non-explicit meanings, such as suggestions, implications and likes" (30). George Yule sees it as an additional conveyed meaning (146). Taking extra mile to unravel certain meaning by achieving a target goal in defined mission.

J. Meibauer in his own notions states that, "Because the implicature ('. . . not all . . .) triggered by some arises in both contexts, it is relatively context-independent" (365). This is achieved by understanding the context in a given priority. In considering this, leaders should be accountable of certain things they say or do in the guise of playing to the gallery or the so called playing politics with the followers' ideas. Anita Fetzer sees it as context-dependent as she states, "It is at the interpretation interface where context-dependent implicatures are calculated and where 
pragmatics interacts with semantics, syntax, morphology and phonology.

So implicature can be of dependent or independent context by understanding the actual meaning surrounding one's environment and intention of the inference. Implicature is of conversational and conventional, it can be realized through speaker's meaning which extends to what is said and what is implicated: can be comprehended through the conversational and conventional. Meibauer is of the view that:

The distinction between conversational implicatures and conventional implicatures draws on the observation that in coordinations like Anna is rich but she is happy, the truth conditions are just the truth conditions of the coordination Anna is rich and she is happy, with the exception of the contrastive meaning of but. This meaning is not truthfunctional, and it is not context-dependent either; hence, there is some motivation for assuming the category of conventional implicature. (365)

This paper seeks to discuss the outcome of 2019 presidential tribunal at the court of appeal. It also addresses the conventional implicatures on the said election and the implications on Nigerians especially towards their leadership, the social media and the users.

The conventional implicature is the idea derived from Levinson as the "non-truth conditional inferences that are not derived from superordinate pragmatic principles like the maxims, but are simply attached by convention to particular lexical items or expressions" (127) Bublitz, Wolfram and Neal R. Norrick on their own consider conventional implicature that can be either as semantic or pragmatic, depending on how the distinction between 
Ugwu \& Motanya: Conventional Implicatures of the 2019 Presidential Tribunal: Implications for the Nigerian Leadership, Media and Users

semantics and pragmatics is drawn, (14). In the line of thought and various argument, there are certain situations that can be untrue in their approaches despite how people view them. Despite the approach been ideal on people's mind set of the right thing to believe on their own side, others may see same scenario as untrue. The meaning in their language use may be meaningful but the implication on their messages might have great misconstruction and great misrepresentation among the users or the analysts. If for example someone is leaving an environment and decides to inform those behind:

Speaker: I am coming

Hearer: I will be waiting.

The condition is that he is leaving a place but states that he is coming as he goes, the non-truth condition is that the person is not coming back, as he or she leaves that particular location at the moment. It is of great notice to remember that the office of Minister of Information came up with the slogan of rebranding Nigeria around 2009 and 2010 with these conventional implicature of Good People: Great Nation! One may ask the great question of, if actually Nigeria is a great nation? If we are generalised as good people why do we still queue to elect leaders, cheat one another, manipulate certain issues and still continue with non-truth statement of been good people? Note that being good is an attribute of been positively great in deed but there is general statement of being the good people which by implication the great majority are not.

For these, Fetzer is of the opinion that, "Implicatures do not exist in isolation. Instead, they are generated in a cognitive context and they have contextual effects, which result from the retrieval of explicatures and the mental operations of reference assignment, 
disambiguation and enrichment" (17). So with the effects they generated, there tend to be loss of confusion among the users because of non-truth condition of the statements produced.

\section{Theoretical Framework and Methodology}

This work was basically analysed with the theoretical framework of multi-modality theory which fits in for the work due to its interest areas on media visuals. Ledin Per and David Machin have been helping in championing the theory, they state that, "Multimodality is becoming more common in CDA as scholars begin to introduce visual sound and material design alongside their analyses of texts" (60). If such theory is employed, it will boost the research nature of this to enviable height. This work was analysed using some media messages generated in the course of gathering the materials. As they opine that, "Reading Images and The Language of Displayed Art extended the social interpretation of language and its meanings to different aspects of visual communication" (61). The purposive nature of the data was engaged too, for the peculiar nature of the study. So, purposive sampling technique was used, especially those data that fit in, in the course of the research. So such data were collected and collated using qualitative research to see the actual contents of social media users, in the course of the actual implication of the judgement's outcome.

\section{Presidential Election and Implications of the Outcome of the Tribunal}

The said election was earlier scheduled to hold on 16th February 2019 but at the early hours of the day the Independent National Electoral Council (INEC) Chair, Prof Mahmoud Yakubu announced the postponement of the election to 23rd February. The general election was later conducted on that day joined with the 
Ugwu \& Motanya: Conventional Implicatures of the 2019 Presidential Tribunal: Implications for the Nigerian Leadership, Media and Users

National Assembly elections. The winner of the election was declared after four days of collation by the INEC Chair. The tribunal sittings lasted for five months before the judgement was delivered and upheld the very winner that was returned elected on 27th day of February 2019.

In lieu of petitioner's prayer some points were raised to nullify the election or declared the petitioner rightfully winner of the election. But the panel of justices ruled otherwise and upheld the elected president as the winner. One of the areas of the judgement was on certificate of the Respondent Applicant which the tribunal overrule and stated that on the page 9 of the judgement issues 1 and 2:

2. WHETHER THE 2ND RESPONDENT SUBMITTED TO THE 1ST RESPONDENT AFFIDAVIT CONTAINING FALSE INFORMATION OF A FUNDAMENTAL NATURE.

The submissions of Learned Senior Counsel to the 1st Respondent on the above united issues can be found on pages 27-34 of 1st Respondent Final Written Addresses. (9)

The summary of above is that the respondent did not possess the certificates relating to the qualifications which the claimed in his CF001 to possess that is

a) First School Leaving Certificate

b) West African School Certificate WASC and

c) Officer Cadet, all of which Learned Counsel seated were not attached to Exhibit P1. (29)

The ruling on the affidavit matter was stated with these conventional implicatures which state that: 
The Petitioners have relied on section 76 and 31(4) of the Electoral Act 2010 as amended that is compulsory for 2nd Respondent to attach evidence of qualification to FORM CF001.

Section 31(4) of the Electoral Act provides:

"31(4) Any person may apply to the commission for a copy of nomination form, affidavit and any other document submitted by a candidate at an election and the commission shall, upon payment of a prescribed fee, issue such person with a certified copy of document within 14 days".

The above section of the Electoral Act 2010 does not say any such thing. In any event Section 31(4) of the Electoral Act must be read together with Section 31(2) of the Electoral Act which provides: -

"31(2) the list or information submitted by each candidate shall be accompanied by an Affidavit sworn to by the candidate at the Federal High Court of a State or Federal Capital Territory indicating that he has fulfilled all the constitutional requirements for election to that office."

The reasonable inference or plausible meaning attached to the above provision of Electoral Act 2010 as amended is that a Candidate can list information concerning evidence of his qualifications or other relevant information(s) about himself. The demand or information required in Form CF001 cannot be more or higher than the statutory requirements. (83-4)

The above statutory ground by the judgment raises uproar on that simple affidavit. The word was practically given diverse meaning because of non-truth condition seen in it. The leadership of Nigeria 
Ugwu \& Motanya: Conventional Implicatures of the 2019 Presidential Tribunal: Implications for the Nigerian Leadership, Media and Users

and the African was given different interpretation. Humanity was fairly not given adequate attention desired for it. As Meibauer also elicited in his words that: "Conventional implicatures are neither calculable, nor variable, nor cancellable. However, they are said to be detachable, i.e., if the elements that trigger them are replaced, the respective implicature does not arise" (366).

The motion arises whether the judgement on the affidavit has the variables to stand the test of time? Did it happen because of party involved, when it will happen to party $\mathrm{B}$ or $\mathrm{C}$ will it be cancellable or upheld in such error? So many question begging for answer. Konig infers that because this meaning appears to be neither truth-conditional nor context-dependent. C. Caffi deduces that conventional implicature respect the truth condition (761), which is primarily lagging in that judgment. Note that after the judgement the petitioner's party made a press statement signed by her National Publicity Secretary: Kola Ologbondiyan which reads thus:

Verdict, A Subversion of Justice, Says PDP... Heads to Supreme Court

The Peoples Democratic Party (PDP) completely rejects the judgment of the Presidential Election Petition Tribunal describing it as provocative, barefaced subversion of justice and direct assault on the integrity of our nation's justice system.

The party is particularly shocked that the tribunal failed to point to justice despite the flawless evidence laid before it, showing that President Buhari was not only unqualified to contest the election but also did not score the majority of valid votes at the polls.

The PDP finds as bewildering that a court of law could validate a clear case of perjury and declaration of false 
information in a sworn affidavit, as firmly established against President Muhammadu Buhari, even in the face of incontrovertible evidence.

The party is also rudely shocked that the Court took over the roles of the Respondents' lawyers who clearly abandoned their pleadings by refusing to call evidence in defence of the petition. The court raked up all manner of excuses to make up for the yawning gaps occasioned by the total absence of any evidence from the Respondents.

Nigerians and the international community watched in utter disbelief when the tribunal ruled that one need not provide a copy or certified true copy of educational certificate such individual claimed to possess, contrary to established proof of claims of certification.

The party notes as strange that the court even went ahead to provide rationalizations in favour of President Buhari, even when all hard facts before it shows that he did not possess the claimed educational certificate and that the Army was not in possession of his WAEC certificate as claimed in the affidavit he deposed to in his Presidential nomination form.

The PDP also described as shocking that the court approved the flawed declaration of President Buhari as the winner of the election despite evidence to show the perpetration of illegalities, manipulations, alterations and subtraction of valid votes freely given to Atiku Abubakar by Nigerians.

Indeed, the pervading melancholic atmosphere across our nation since the verdict is a direct indication that the judgment has not fulfilled the desires and expectations of Nigerians. 
Ugwu \& Motanya: Conventional Implicatures of the 2019 Presidential Tribunal: Implications for the Nigerian Leadership, Media and Users

The PDP however encouraged Nigerians to remain calm and not to lose hope or surrender to despondency or selfhelp, as our lawyers are upbeat in obtaining justice at the Supreme Court.

This is more so as the tribunal itself admitted that there are several errors in the judgment.

\section{Implications and Analysis of the Data Collected}

The data for the research of this work were gathered mainly from various social media especially from WhatsApp groups and some from Facebook social media. By implication due to sensitive nature of this work and the judgement some phone numbers that appeared in the course of collation was blocked to maintain absolute confidentiality except that the names stored by the researchers were retained because the names were not properly ideal as the real proper nouns.

\section{Data 1}

A support over the judgement and the rejoinder from another person. In the first exhibit support Mr Umembamalu was of the opinion that PDP and her candidates could not prove beyond the reasonable doubt to update their petition and he supports with this argument on a WhatsApp group and the study italicised his point on affidavit for more emphasis that:

Atiku couldn't gather enough evidence to prove his case beyond reasonable doubts. The INEC server issues, over voting, use of force etc. could not be proved sufficiently by his legal team juxtaposing Electoral Act, Guidelines and 1999 Constitution as Amended.

... In jurisprudence, being a petitioner is a daunting task. PDP, opposition, CLOs lost the election the very day they 
failed to override PMB veto for enacting new electoral law that will empower INEC to use electronic means for our elections. Prof. Mahmud was handicapped right from the beginning.

As for the qualification of PMB, the Judges holds that he is eminently qualified, so do I even before the judgement.

The grounds on qualification for the office of President isn't ambiguous in our constitution. That he deposed an affidavit for school cert doesn't mean he never possessed FSLC, or Service in Civil/Public service for period less than 10 years, Military training etc. Since the petition before the judges was to ascertain if he was qualified as INEC was striped with the powers to disqualify Candidate (Atiku/INEC Supreme court ruling) based on document submitted before them. This make the case a post-election or tribunal matter. Having examined what, the law stipulates for qualifications, the judges found no merit in their petition.

Justice was clearly served!

Mr Akujobi on same group came with a tagged reply over the submissions above and argues that:

I totally disagree with you in the area of PMB's qualification. The bone of contention is not that he is not qualified but that he lied on oath. He said he has a school certificate and that it is with the military which the military denied, what do you call that. PMB's form CHF001 has two affidavits attached to it, one is to ascertain that all he filled in his form are correct, then second is that his school cert is with the military. There would not have been any need for 
him to make a second affidavit if his certificate was attached. Please let's know that the courts have disqualified several people from contesting elections on the grounds of certificates in this country, the most recent was in Yola which was determined by the supreme Court. Again even the certificates/attestations produced by Buhari were full of discrepancies in first name and number of subjects sat. Please let's be guided appropriately and stand by the truth and may God use the supreme Court to deliver Nigeria from the impending doom facing it with this judgement of the appellate Court.

The outcome of the judgement still lies that sentiment still abounds in area of that grey environment of the affidavit on certificate, which Mr Akujobi was trying to point that if there is evidence of the certificate while the affidavit? It still boils down to the issues on non-truth condition of the judgement.

\section{Data 2}

There is this implication of the social media mockery of the judgement by bringing funny posts over incidence that transpired in that conventional implicature election tribunal which states with the followings:

\#Malam Audu Affidavit Procurement Services Ltd

Superior to Certificates... Save time and money!!!

Scale of FEES (PROMO):

Nursing Affidavit - 1k

For Lawyer Affidavit - 2k

For Engineer Affidavit - 2k

Doctor Affidavit - 2k

For Professors Affidavit - 4k 
Army General Affidavit - 5k

Rev. Father Affidavit - 7k

Imam Affidavit - 7k

All Purpose Affidavit - 10k

(PAY 3 \& GET 1 FREE!!!)

Visit us at Number 419, Mnafiki Road, Daurana, Nigeria

Call us on 080888888419

To download Affidavit and pay online, Visit:

In above, it seems that affidavit is moving towards a different direction of non-truth notions of things in existence. The sequential cause is the outcome of the judgement. The number above may be politely wrong because of the satirical address provided for a visit also note the last three digits in it. Such digits are equivalent to vice and cheat in Nigerian context. No place added for the download of affidavit and the online payment. See the screenshot as a support for the data 2 in another edited update. 
Ugwu \& Motanya: Conventional Implicatures of the 2019 Presidential Tribunal: Implications for the Nigerian Leadership, Media and Users

\section{Data 3}

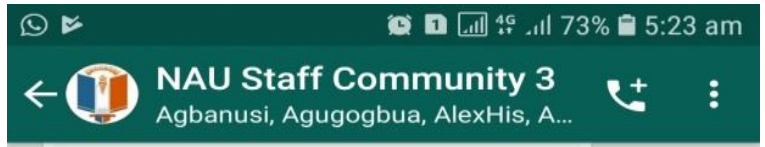

295 pages - PDF

7:49 pm

Prof Luke

$\Rightarrow$ Forwarded

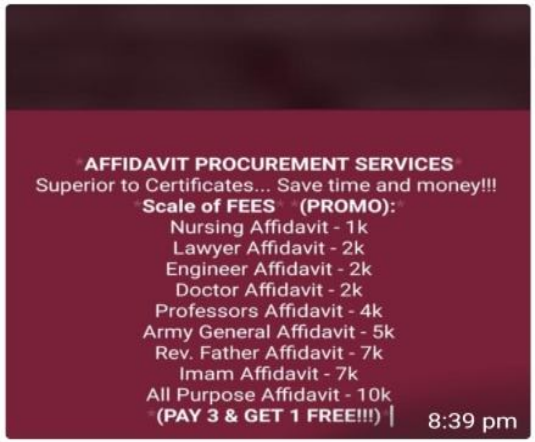

\section{AlexHis}

Prof Luke

or Photo

This is what it boils down to. The address of this important company is missing I need their urgent services.

$8: 42 \mathrm{pm}$

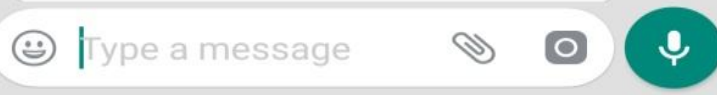




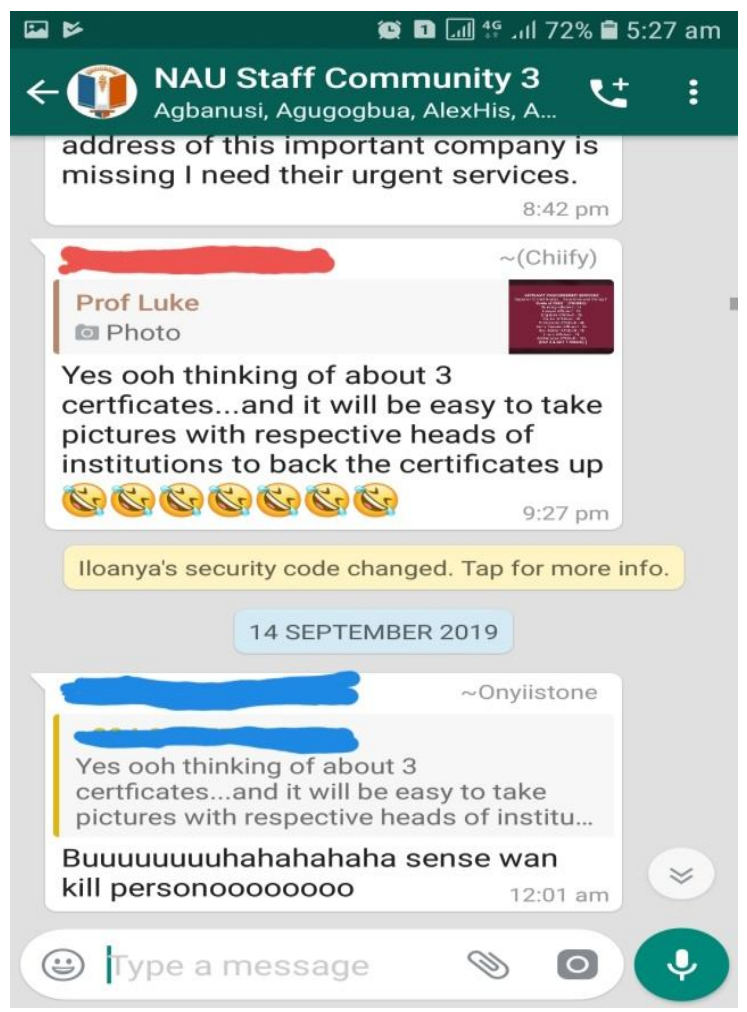

An immediate reply on the above picture makes its assertion of what the Nigerian Leadership is heading to in the course of the same affidavit. Another tagged reply over the picture made another jest of procuring 3 certificates through same affidavit which is of non-truth condition. The reply gave room in another group with the ideas of generating various certificates. 
Ugwu \& Motanya: Conventional Implicatures of the 2019 Presidential Tribunal: Implications for the Nigerian Leadership, Media and Users

\section{Data 4}

\section{国}

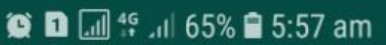

\section{NAU Staff Community 2}

AdaDn, Ajulu, Aloy, Amaka, Arinze...

Aloy Nebo

12 SEPTEMBER 2019

I have just sworn dil dilluavil unat:

1. I am a Professor

2. I have $2 \mathrm{PHDs}$, one in Medical

Engineering and another in

Political Pharmacy.

3. I have graduated 358 PHD students in NAU from March 2019 -September 2019.

The Bursary and Personnel units should take note and act immediately.

Thanks.

\section{Music Oracle}

Aloy Nebo

I have just sworn an affidavit that:

1. I am a Professor

2. I have 2 PHDs, one in Medical Engine...

\section{$\because \cdot 0 \cdot 0 \cdot 0 \mathrm{hmmm}$}




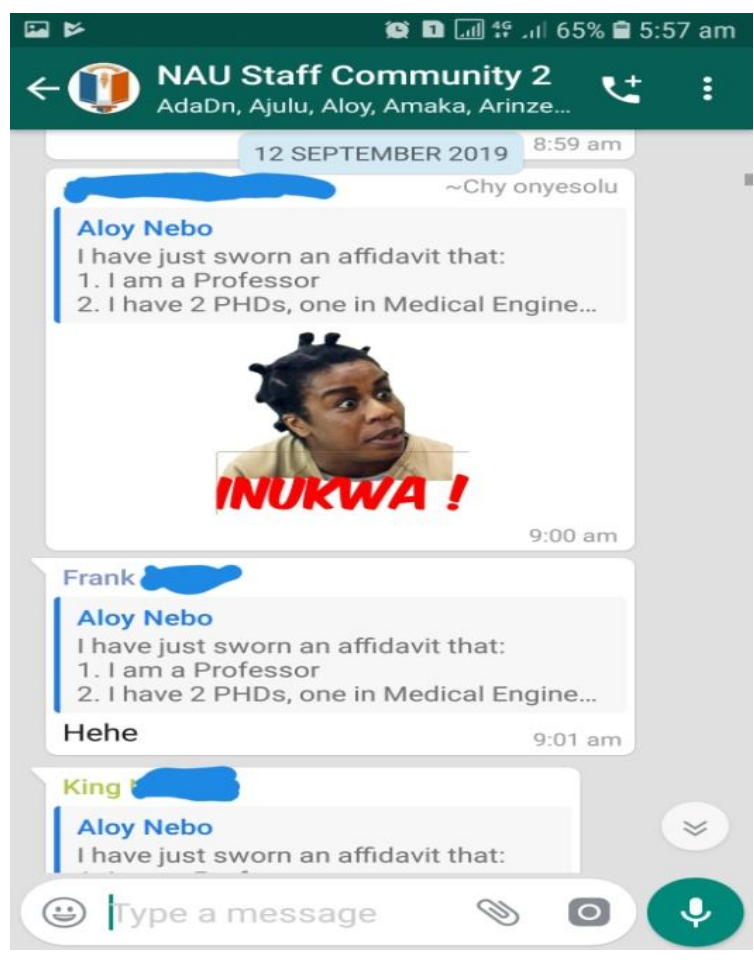

The comment made a day after the judgement had the implication which claimed that: I have just sworn an affidavit that:

1. I am a Professor

2. I have 2 PHDs, one in Medical Engineering and another in Political Pharmacy.

3. I have graduated 358 PHD students in NAU from March 2019 September 2019.

The Bursary and Personnel units should take note and act immediately.

Thanks. 
Ugwu \& Motanya: Conventional Implicatures of the 2019 Presidential Tribunal: Implications for the Nigerian Leadership, Media and Users

The comment attracted serious replies of emojis, smiley, emoticons and stickers of great surprise of the claimant and which gear towards pointing at the leadership position the nation.

\section{Data 5}

In another scenario some school was able to abuse the political party in power acronym into different meaning. The meaning was attributed to the so called judgement delivered which states thus:

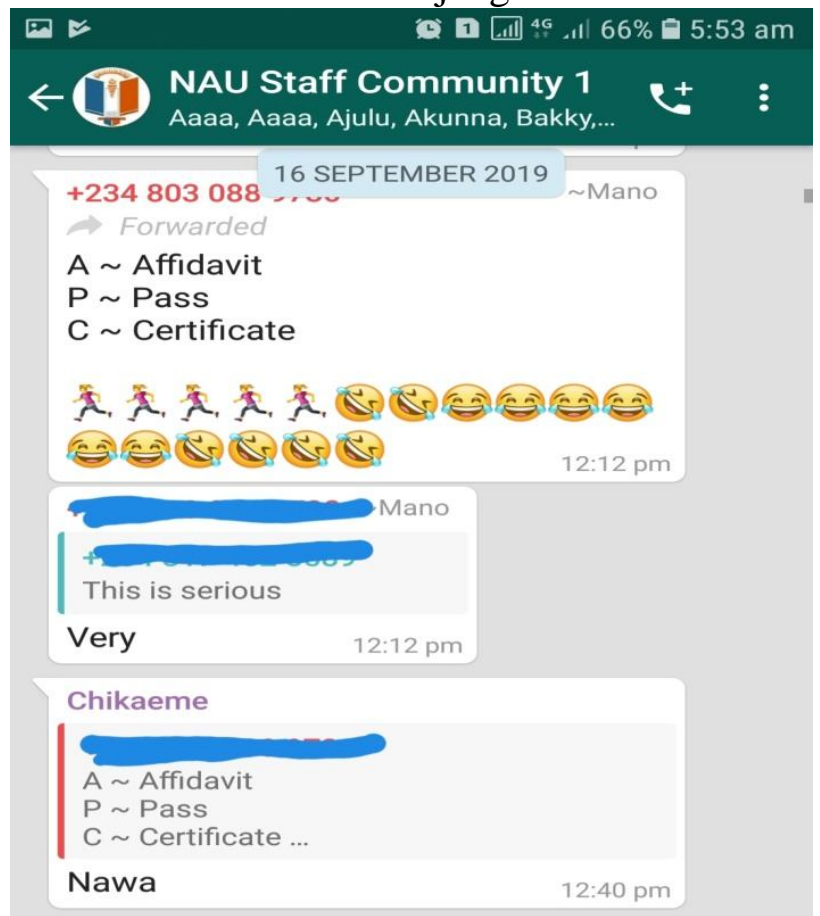

The ideology in above is that definitely, certificate has no locus stand in our government once you are able to produce any affidavit from any competent court of law. 


\section{Conclusion}

Conventional Implicature has it way of contesting various things into various situations as Chinwe Ezeifeka is of the view that "the addressee is entitled to draw inferences about the speaker's beliefs and intentions, based on non-truth functional components of the utterance" (89). Those in charge of discharging the rightful duties should try their best to do so considering the implication it will have on the masses.

The presidential election tribunal has done hers but what lies in the future as another implicated implicature to hold on. It will be definitely being a model to cite as an example when the time comes. The implication lies that things should be done in the rightful manner to avoid misguided information where it ought not to be. Nigerian constitution of 1999 need thorough overhauling in terms of stipulating what ought to and what ought not to be, considering the helplessness of the Tribunal not to further interpret the locus of the constitution.

\section{Emmanuel Chukwudi Ugwu}

Department of English Language \& Literature

Nnamdi Azikiwe University, Awka

Nnambra State

ec.ugwu@unizik.edu.ng

\&

Chukwuma Charles Motanya

Aminu Saleh College of Education, Azare

Bauchi State

charlliusaid@gmail.com 
Ugwu \& Motanya: Conventional Implicatures of the 2019 Presidential Tribunal: Implications for the Nigerian Leadership, Media and Users

\section{Works Cited}

Bublitz, Wolfram and Neal R. Norrick. "Introduction: The Burgeoning Field of Pragmatics." Foundations of Pragmatics. Eds. Bublitz, Wolfram, Neal R. Norrick and Klaus P. Schneider. Vol.1. Berlin: De Gruyter Mouton, 2011. 1-20. Print.

Caffi, C. "Pragmatic Presupposition" Concise Encyclopedia of Pragmatics. 2nd ed. Ed. Mey, Jacob L. Oxford: Elsevier Ltd., 2009. 759-67. Print.

Ezeifeka, Chinwe. Discourse Analysis: Concepts and Approaches. Awka: Patrobas Nigeria Limited, 2018. Print.

Fetzer, Anita. Recontextualizing Context: Grammaticality Meets Appropriateness. Amsterdam: John Benjamins Publishing Co, 2004. Print.

_ _ _. "Pragmatics as a Linguistic Concept." Foundations of Pragmatics. Eds. Bublitz, Wolfram, Neal R. Norrick and Klaus P. Schneider. Vol.1. Berlin: De Gruyter Mouton, 2011. 23-50. Print.

Konig, E. The Meaning of Focus Particles: A Comparative Perspective. London: Routledge, 1991. Print.

Levinson, Stephen. Pragmatics. Cambridge: CUP, 1983. Print.

Meibauer, J. "Implicature" Concise Encyclopedia of Pragmatics. 2nd ed. Ed. Mey, Jacob L. Oxford: Elsevier Ltd., 2009. 365-78. Print.

Verschueren, Jef. Understanding Pragmatics. London: Hodder Arnold, 2003. Print.

The Court of Appeal Presidential Election Petition Court, Judgement Delivery on 11th Day December 2019, Abuja.

1999 Constitution of the Federal Republic of Nigeria with Amendments 2011. 